\title{
A víz- és tápanyagellátottság, illetve -hasznosulás megítélésének kérdései kukorica terméseredmények vonatkozásában
}

\author{
${ }^{1}$ RÁCZ CSABA-²NAGY JÁNOS \\ Debreceni Egyetem Agrár- és Gazdálkodástudományok Centruma \\ ${ }^{1}$ Agrometeorológiai Obszervatórium, Debrecen \\ ${ }^{2}$ Földhasznosítási, Múszaki és Területfejlesztési Intézet, Debrecen
}

\begin{abstract}
Összefoglalás
A növényállományok vízellátottságának megítélése nagymértékben függvénye a választott mérôszámnak, illetve az ahhoz tartozó referencia idôszaknak. Különbözô hosszúságú időszakok csapadékösszegei, illetve egy vízellátottsági index került összehasonlításra a Debrecen-Látóképen beállított többtényezôs szántóföldi kukorica tartamkísérlet eltérố tápanyag-kezelési szinteken és öntözés mellett vagy a nélkül elért terméseredményeivel való korrelációja alapján. Meghatározásra került a trágyakezelések közül adott körülmények között legjobban hasznosuló tápanyagdózis nagysága, illetve a vízhasznosulás tápanyagszinttől való függésének mértéke. Figyelembe véve, hogy a gazdaságos termelés elsốdleges eleme a produkciónak a termelési inputok egy marginális hatékonysági szintjéig történố növelése, valamint a termésbiztonság ezen belüli maximalizálása, konkrét ajánlások kerültek közlésre a leghatékonyabb tápanyagszint, illetve az ehhez tartozó öntözôvíz-igény tekintetében.
\end{abstract}

Kulcsszavak: kukorica, vízellátottság, vízhasznosulás, tápanyag-hasznosulás 


\title{
Aspects of the judgement of water and nutrient supply and utilisation in relation to maize yield
}

\author{
${ }^{1} \mathrm{CS}$. RÁCZ-2J. NAGY \\ University of Debrecen, Centre for Agricultural and Applied Economic Sciences \\ ${ }^{1}$ Agrometeorological Observatory, Debrecen \\ ${ }^{2}$ Institute for Land Utilisation, Regional Development and Technology, Debrecen
}

\begin{abstract}
Summary
The judgement of the water supply of crop populations largely depends on the chosen index number and the related reference period. The precipitation sums of different length periods and a water supply index were compared on the basis of their correlations with the yield obtained on different nutrient treatment levels and under irrigated or non-irrigated conditions in a multifactoral long-term field experiment on maize established in Debrecen-Látókép. The nutrient dose that can be utilised the best under the given circumstances and the dependence of the water utilisation from the nutrient level were determined. Considering that the primary element of economical production is the increase of production to a marginal efficiency level of production inputs and the maximisation of yield safety, specific recommendations were provided in relation to the most effective nutrient level and its associated irrigation water need.
\end{abstract}

Key words: maize, water supply, water utilisation, nutrient utilisation 


\title{
Вопросы оценки обеспеченности водой и питательными вешествами и их использования в отношении результатов урожаев кукурузы
}

\author{
1Ч. РАЦ-2Я. НАДЬ \\ Центр Агро-Экономических наук Дебреценского Университета \\ ${ }^{1}$ Агрометеорологическая Обсерватория, Дебрецен \\ ${ }^{2}$ Институт Землепользования, Техники и Развития территорий, Дебрецен
}

\begin{abstract}
Резюме
Оценка водообеспеченности растительных насаждений в большой мере зависит от выбранного показателя, а также от референции, относящейся к этому периоду. Суммы осадков различных по продолжительности периодов, точнее один индекс водообеспеченности сравнили в проведённом в Дебрецен-Латокейпе (Debrecen-Látókép) многофакторном пахотном кукурузном продолжительном опыте на различных уровнях обработок питательными веществами при орошении или без него на основе корреляции полученных результатов урожаев. Определили величину лучше всего использованной дозы питательного вещества среди обработок удобрениями в данных обстоятельствах, а также меру зависимости водоиспользования от уровня питательных веществ. Учитывая, что первичный элемент рентабельного производства - увеличение до маргинального уровня эффективности производственных «input»-ов продукции, а также максимализация безопасности урожая при этом, сообщаются конкретные предложения относительно самого эффективного уровня питательного вещества и относящейся к этому потребности в воде орошения.
\end{abstract}

Ключевые слова: кукуруза, водообеспеченность, водоиспользование, использование питательного вещества

\section{Bevezetés}

Klimatikus szempontból Magyarországon a kukoricatermesztés legfőbb korlátozó tényezóje a csapadék bizonytalansága, rajta keresztül pedig a megfelelô vízforgalom gyakori zavara. A ritkábban előforduló túlzott vízbőség éppúgy 
káros, mint a jóval gyakoribb gyenge vízellátottságú idôszakok. A vízhiány már közvetlen módon is gátolja a tápanyagfelvételt, hiszen a növény csak oldat formájában képes felvenni a szükséges tápelemeket. A nem elégséges vízellátás azonban a növényi vízháztartás felborulásán keresztül a tápanyag-hasznosulást is kedvezôtlen irányban befolyásolja, így vezet végsố soron terméskieséshez.

A kukorica víz- és tápanyagforgalmának szoros interakciója régóta ismert, hazánkban és külföldön is számtalan kutatásnak képezi tárgyát. Ugyancsak ôsi törvényszerúség, hogy a két tényezó hasznosulása is egymásra utalt; optimális vízellátottságnál a tápanyaghasznosulás maximális, illetve harmonikus tápanyagellátottság esetén lesz a legjobb a vízfelhasználás hatásfoka. A termésszint fokozatos emelkedése révén ennek mind nagyobb szerep jut gazdasági megfontolásokból, de az optimális ellátottság számszerúsítése azért is bír nagy jelentôséggel, mert elsődlegesen a folyamatosan és gyorsuló ütemben fejlôdố biológiai alapok függvénye, így számértékében maga sem állandó. Emellett a többi ökológiai és agrotechnikai tényező befolyásoló szerepe sem hanyagolható el (Szalóki 1988), ezek egyben eszközt is jelentenek a termesztó kezében. Ugyanakkor a víz- és tápanyagellátottság relatív fogalmak, ezek adott, vagy optimális mértékének megítélése is gyakran nehézkes, legalábbis semmiképpen sem egyszerúsíthetô le puszta csapadékösszegek és hatóanyagdózisok közlésére.

A két tényezô kölcsönhatásának vizsgálata már a múlt század második felétốl fogva központi kérdés volt az agronómiai kutatásokon belül (Hank és Frank 1951, Debreczeniné 1964, 1969). A növény vízellátottsága és a tápanyaghasznosulás közötti szoros korreláció már ekkor igazolást nyert, a késôbbiekben is több tanulmány született az optimális víz- és tápanyagmennyiségek számszerúsítésére. Átlagos termőhelyi viszonyok mellett, és a talajban már meglévố tápanyagkészletet is figyelembe véve, viszonylag magas értékekben (120-240 kg N, 50-120 kg P, illetve 50-140 kg K) állapították meg a kukorica számára kívánatos adagokat (Dorogi 1987, Csathó et al. 1989). Összehasonlításképpen Nagy (1995) a Debrecen-látóképi kísérleti eredmények alapján 90-120 $\mathrm{kg} / \mathrm{ha} \mathrm{N}$ hatóanyagdózist tekint optimálisnak. Az értékek termóhely-specifikusságára való tekintettel sok esetben eleve régióra, vagy talajtípusra szabott értékeket találunk a szakirodalomban, melyekhez további korrekciók is járulnak az évjárathatást, illetve egyéb agrotechnikai és ökológiai tényezőket is figyelembe véve (Berzsenyi 1993). A vízellátottsági anomáliák káros hatásainak mérséklését célzó korrekció jellemzően a NPK-adagok csökkentéséből áll, 
amennyiben a tenyészidôszak korai szakasza, vagy a megelőző évjárat száraz. Húvös, túlzott csapadékú évjáratokban (600 mm<) vagy azokat követôen pedig az emelt dózisú N-trágyázás lehet kimondottan alkalmas a terméskiesés csökkentésére (Ruzsányi 1997). Debreczeni (1994) viszont száraz, aszályos évek után a N-adag emelésében, a P és K-adag csökkentésében látja a korrekció helyes irányát. Számos szerzô igazolta, hogy a víz hasznosulása tápanyagellátás optimuma környékén a legjobb (Ruzsányi 1973), az Országos Mútrágyázási Tartamkísérletek eredményei alapján N-mútrágyázás hatására ez 4-5 kg/ha/mmrel nőtt, míg a P-adagolás nem növelte szignifikánsan. Nagy és Huzsvai (1995) vizsgálatában a tenyészidő csapadékhasznosulása $23 \mathrm{~kg} / \mathrm{mm}$ volt. Szász (1998) 120 éves idősort vizsgálva kimutatta, hogy a vízhasznosulási együttható (WUE) az 1960-as évek óta a genetikai elôrehaladás révén jelentősen nôtt, az akkori 12,2-16,1-rôl egy évtized alatt is $17 \mathrm{~kg} / \mathrm{mm}$ körülire emelkedett, napjainkra pedig már jóval efölötti, kedvezó vízellátásnál mútrágyázás mellett akár 35,8-61 kg/mm (Debreczeniné 2009).

A tápanyag-hasznosulás vízellátottságtól függô dinamikájának vizsgálata kapcsán ugyancsak születtek újabb eredmények, e dinamika a vízhasznosulással megegyezóen optimumgörbével jellemezhető (Pummer et al. 1995). Ezzel együtt a víz hasznosulásának hatásfoka a tenyészidô során is változik, maximumát a nôvirágzás körüli 6-7 hétben éri el (Shaw és Dale 1959). Szász (1997) szerint a kukorica napi vízigénye a szárbainduláskor 1-2, míg virágzás idején a $3 \mathrm{~mm}$-t is meghaladhatja. Ezzel kalkulálva a tenyészidei vízszükséglet Magyarországon 320-490 mm között alakul. A Hajdúhát térségében hozzávetőleg 400 mm (Szász 1988, Varga-Haszonits és Varga 1999). A tenyészidőszak természetes csapadéka ezt ritkán fedezi önmagában, de előfordul, hogy a talajban tározott mennyiséggel együtt sem. Nagy (2007) megállapítja, hogy öntözéses gazdálkodásban eme évjárathatás mérsékelhető, a trágyahatás pedig ezzel párhuzamosan növelhető. A trágyahatás maximalizálása csak ily módon biztosított, illetve az öntözóvíz jó hatásfokú felhasználásához éppúgy szükséges a tápanyagpótlás. A nyári, intenzív párologtatással, vízfelhasználással járó időszakban az alföldi termőkörzetekben a termésbiztonság elfogadható szintre emeléséhez tehát szükséges az öntözés. Antal (2001) a kukorica öntözôvíz igényét átlagosan $82 \mathrm{~mm}$-ben határozza meg, ennyivel kevesebb víz áll tehát rendelkezésre az optimális evapotranspirációhoz. Kritikus tényezô azonban ennek ütemezése, időzítése, tekintettel a nyári csapadék nagy statisztikai bizonytalanságára, változékonyságára. A csapadék és az öntözóvíz tárolhatósága 
és a növény számára elérhetôvé tétele szempontjából lényeges a talajok vízkapacitása (Ruzsányi 1989). A rendelkezésre álló vízmennyiség kalkulációjakor tehát tekintetbe kell venni a talajok eme pufferkapacitását, a bennük tárolt mennyiséget is. Jelen munka ennek megfelelóen a puszta csapadékmennyiségekre alapuló számításokat ötvözi a Szász-féle vízellátottsági indexre épülô vizsgálatokkal. Ez ugyanis a tenyészidei csapadékmennyiségen kívül figyelembe veszi a tenyészidôn kívül hulló, de a talajban tározódva a növény számára még elérhető vízmennyiséget is (Szász 1991).

\section{Anyag és módszer}

A vizsgálat anyagául szolgáló termésadatok a DE AGTC Földhasznosítási, Múszaki és Területfejlesztési Intézet Debrecen-Látóképen beállított többtényezős szántóföldi tartamkísérletéból származnak. A talajmúvelés, növényszám, genotípus, öntözés és mútrágyakezelések közül a vizsgálat szempontjából csak utóbbi kettő volt lényeges, így a termésadatok kimondottan ezekre nézve kerültek kiértékelésre. Ennek megfelelően az elemzés háromféle mútrágyázási [kontroll (Ø), N:120- $\mathrm{P}_{2} \mathrm{O}_{5}: 90-\mathrm{K}_{2} \mathrm{O}: 106(\mathrm{~N}-120)$, illetve $\mathrm{N}: 240-\mathrm{P}_{2} \mathrm{O}_{5}: 180-\mathrm{K}_{2} \mathrm{O}: 212$ (N-240) kg hatóanyag/ha], illetve kétféle öntözési (kontroll, öntözött) kezelésre készült el. Az öntözóvíz kijuttatott mennyisége évenként változó, 20-270 mm közötti volt, igénytől függôen.

A kísérleti terület talaja: Lösz alapkőzeten képződött jó termőképességú alföldi mészlepedékes csernozjom borítja a Kísérleti Telep területét, ennek fizikai és kémiai tulajdonságait az alábbi néhány paraméterrel jellemezhetjük:

A talaj kémhatása 6,2 pH körüli, mésztartalma 10-13\%, humusztartalma 2,8-3,0\% közötti, higroszkópossági értéke (hy ${ }_{1}$ 2,63, Arany-féle kötöttségi száma pedig 43. E két utóbbi érték alapján fizikai féleség szempontjából középkötött vályogtalajról beszélhetünk. A talajvizsgálatok további eredményei szerint a talaj $\mathrm{N}$ és P-ellátottsága közepesnek (Al-oldható $\mathrm{P}_{2} \mathrm{O}_{5}$ : 130-200 $\mathrm{mg} / \mathrm{kg}$ ), K-tartalma jónak bizonyult (Al-oldható $\mathrm{K}_{2} \mathrm{O}: 240-280 \mathrm{mg} / \mathrm{kg}$ ), mikroelem-hiány nem jellemzô. Kiemelendô még a talaj 70-90 cm mély humuszos rétege, valamint az, hogy a talajvíz szintje 6-8 m között helyezkedik el, így belvíz szempontjából általában kevéssé veszélyes a terület. A talaj vízkapacitása nagy, a hasznos VK 0-100 cm-en 157 mm, a 100-200 cm-es szelvényben pedig $150 \mathrm{~mm}$. 
A terméseredmények értékeléséhez a vizsgált évek (1989-2007) havi csapadékösszeg- és középhőmérséklet adatait a DE AGTC Agrometeorológiai Obszervatóriuma szolgáltatta.

Az öntözés és az egyes tápanyagkezelések terméseredményekre gyakorolt hatását, illetve a két tényezó interakcióját a kukorica tenyészidejére, vagy aktív növekedési időszakára számított csapadékösszegeken kívül vízellátottsági mutatók tükrében is értékelhetjük. A Szász-féle vízellátottsági index (VE, dimenzió nélküli szám) kiszámításának módja (1. egyenlet) az alábbi:

$$
V E=\left[\frac{1}{F} \cdot C s(X I I-V) \cdot \frac{10 \cdot \sum C s(V I-V I I I)}{0,2 \cdot \sum T(V I-V I I I)}\right] \cdot \frac{67}{R N}, \text { ahol }
$$

F: a nyarat megelőző tél és tavasz csapadékát kifejezô paraméter

Cs (XII-V): a decembertôl májusig tartó időszakban mért csapadékösszeg $(\mathrm{mm})$

Cs (VI-VIII): a június-augusztusi időszak csapadékösszege (mm)

T (VI-VIII): a június-augusztusi idôszak havi középhőmérsékleteinek összege $\left({ }^{\circ} \mathrm{C}\right)$

RN: a relatív páratartalom átlagos értéke a három nyári hónapban (\%)

Az F-paraméter pontos meghatározási módját, illetve a VE kiszámításának és elméleti hátterének részletesebb leírását lásd: $S z a ́ s z$ (1991). A formula másképpen is felírható, a számításokat ezen egyszerúbb változat (2. egyenlet) felhasználásával végeztük:

$$
V E=\frac{1}{F} \cdot C s(X I I-V) \frac{10 \cdot \sum C s(V I-V I I I)}{P E T(V I-V I I I)}
$$

A képletben a PET (VI-VIII) rövidítés a június-augusztusi potenciális evapotranspiráció összegét jelenti mm-ben (Szász 1991).

Az egységnyi termés (vagy biomassza) előállításához szükséges víz mennyiségét a transzspirácós együttható fejezi ki (3. egyenlet). 
Transzspirációs együttható= $\frac{\text { vizmennyiség }(\mathrm{mm})}{\text { szárazanyag }(\mathrm{kg})}$

A mutató a szemtermés mennyiségére is felírható, illetve a felhasznált víz mennyisége utalhat a tenyészidei (vagy egyéb idôtartamokra megállapított) csapadékmennyiségre, vagy a tényleges evapotranspiráció számértékére is, ennek megfelelóen a szakirodalomban igen eltérô értékekkel találkozhatunk. A transzspirációs együttható alkalmazása inverz módon felírva is elterjedt, ekkor vízhasznosulási mutatót (water use efficiency, WUE) kapunk, mely kifejezi egységnyi csapadékmennyiségre, öntözővízre, vagy evapotranspirációra jutó szárazanyag mennyiség vagy szemtermés nagyságát. Jelen vizsgálatokban is ez utóbbi formát alkalmaztuk, mégpedig az április-augusztusi idôszak csapadékára vonatkoztatva.

\section{Eredmények és azok értékelése}

Gyakorlati oldalról megközelítve a témával kapcsolatos vizsgálatokat, érdeklődésre elsôsorban azok az információk, adatok tartanak számot, amelyek az agrotechnikai kérdésekben meghozandó döntéseket érdemben is támogatni képesek. Lényeges tudnunk, hogy adott tápanyag-ellátottsági szinten milyen a kukorica statikus és dinamikus vízigénye, azaz milyen mennyiségben és idôzítéssel kell a víznek rendelkezésre állnia az optimálisan nagy termés kialakulásához. Megfordítva a kérdést, lényeges ismerni az adott vízellátottság mellett legjobban hasznosuló tápanyagdózis nagyságát. Nyilvánvaló, hogy ökológiai és ökonómiai szempontból mást és mást jelent a legjobb hasznosulás intervalluma, a gazdasági szempontok taglalása azonban már túlmutat e munka célján és keretein.

\section{A vízellátottság számszerú kifejezésének problémaköre}

Az eltéró évjáratok vízellátottság szempontjából történő megítélése pusztán a csapadékösszegek alapján nehézkes. Szakirodalmi adatok, illetve a tartamkísérlet adatainak tanúsága szerint is meglehetôsen nagy bizonytalanság jellemzi a terméssorok valamint az időszaki csapadékösszegek korrelációját. Ismert ökológiai adottságok között a kukorica tényleges vízigénye és -felhasználása jól modellezhetô, az ily módon nyert párolgási adatok segítségével a vízellá- 
tottság viszonylag pontos meghatározására van lehetôség. Ennek bemenó adatigénye azonban nagyobb, s a módszer ezek pontosságára igen érzékeny. Ezzel szemben a csapadékösszegek évi, tenyészidei vagy egyéb időszakra történő kiszámítása hamis képet festhet a valós viszonyokról. Mindenekelôtt számos tényezô, így a fajta, érési csoport, talajviszonyok, stb. függvénye, figyelembe vehetô az idôszak hossza is, hiszen a lehulló csapadék a talajban tárolódik, s ennek felvehetősége és hasznosíthatósága számunkra lényegesebb, mint maga az idôszaki összeg. A talajok vízbefogadó, -tározó és -szolgáltató képességének ebből a szempontból kulcsszerepe van. Éppen ezen okból kifolyólag adott évszakos csapadékösszegek csakis lokálisan értékelhetők, térségi szinten egymással csak a talaj- és domborzati viszonyok figyelembevételével összevethetôk. További problémát jelent a havi összegeken belül jelentkezô szóródás, ami a csapadék természeténél fogva nagy időbeli és térbeli változékonyságából adódik. Bizonytalansága ráadásul annál nagyobb, minél nagyobbak a havi átlagok, azaz éppen a nyári csapadékmaximum idején, a kukorica legintenzívebb növekedési szakaszában, a május-augusztusi időszakban. Szélsôséges esetben akár egy több hetes szárazság is rejtve maradhat a havi összegen belül, ha azt egy nagyobb, leginkább konvektív eredetú csapadékhullás ellensúlyozza ennek hasznosulása azonban mindemellett többnyire kedvezôtlen is.

Az 1. ábrán háromféle időszak csapadékösszegét figyelembe véve hasonlítottuk össze a kísérletben résztvevô három mútrágyakezelés termésnagyságra gyakorolt hatását. Minden esetben a csapadék nagysága szerint kategorizáltuk az egyes évjáratokat, öntözetlen állománynál csak a természetes csapadékot, öntözöttnél pedig a tenyészidőszak megfelelő tartománya során kijuttatott összes öntözóvíz mennyiségét is. Az éves csapadékösszegek alapján kalkulálva szembetűnő, hogy a csapadékosság növekedtével nem feltétlenül nô a termés, ezt az „anomáliát” egyfelől a referencia-időszak és a kukorica tenyészidejének különbözősége, másfelôl pedig a viszonylag alacsony esetszám ( $n=17)$ figyelembevétele okozza. Amint az várható is volt, a referencia-idôszak hosszának csökkentésével a csapadékmennyiség és a termés nagysága közötti összefüggés nem öntözött állományoknál közelít a lineárishoz, öntözés mellett pedig „telítôdési” jelenség figyelhetô meg. Ugyancsak szemmel látható módon az öntözés biztosíték a szignifikáns termésnövekedésre a kontroll állományokhoz képest mindkét trágyakezelésnél, bármely időszak csapadékát vesszük is alapul. Ezzel szemben a nem öntözött állományokban csakis a $300 \mathrm{~mm}$ feletti csapadékmennyiségnél érvényesül szignifikáns terméstöbblet, s itt is egyedül 
az április-augusztusi idôszakra vonatkoztatva. A tapasztalatok szerint ezen tartomány (ld. az ábra középsố sávja) csapadékmennyiségének figyelembevétele a legcélravezetôbb hasonló összehasonlításokban. 350-400 mm feletti tenyészidei vízmennyiség mellett már nem nô jelentékenyen a termés nagysága, de különösen a $120 \mathrm{~kg} / \mathrm{ha} \mathrm{N}$ hatóanyag-mennyiség feletti trágyázási szint mellett nincs már érdemi termésnöveló hatás, miközben a további tápanyagdózisoknak is jelentôsen romlik a hatékonysága.

A különböző időszakokhoz tartozó csapadékösszegek mellett egyéb vízellátottsági mérőszámok figyelembe vétele is célszerú, tekintettel a vízellátottság megítélhetôségének komplex voltára. Számos lehetôség közül erre a Szász-féle vízellátottsági indexet választottuk ki, melynek bemenô adatigénye csupán havi csapadékösszegekre, illetve átlaghőmérsékletekre és relatív páratartalom adatokra korlátozódik, ugyanakkor adott termôkörzetre történő kalibrálásra mindenkor szükség van. Ennek oka elsôdlegesen a különböző körzetek talajainak vízkapacitásában mutatkozó, esetenként meglehetôsen nagy különbségekben keresendő. A kísérleti terület mélyrétegú, a Hajdúhátra általában is jellemzô mészlepedékes csernozjom talaja a kukorica számára is elérhetô rétegekben csaknem $300 \mathrm{~mm}$ vizet képes raktározni, jóllehet a veszteségek miatt ennek csak egy része hasznosulhat ténylegesen. A vetés körüli, illetve a korai vegetációs időszakban, száraz időjárásban különösen nagy jelentôségú a tenyészidôn kívülrốl ily módon történô „áthozatal”, de a nyári, nem ritkán több hetes száraz idôszakok átvészelése szempontjából is kritikus lehet e tározókapacitás nagysága.

\section{Az öntözés és a trágyakezelések hatékonyságának értékelése a vízel- látottsági mérôszámok alakulásának tükrében}

Vizsgálataink a fentiekben ismertetett két vízellátottsági mérôszámra épültek, ezek alapján kerültek megállapításra a tápanyag- és vízhasznosulási mutatók. Elôzetesen már kimutatható volt, hogy az eredmények nem térnek el lényegesen a szakirodalomban szerepló és a korábbi vizsgálatok során is igazolódott törvényszerúségektôl. Öntözetlen viszonyok között, 17 évjárat átlagában a 120 $\mathrm{kg} /$ ha adagú mútrágyakezelés többlethozama $(\Delta P)$ a kontrollhoz képest 2,05, míg a 240-es kezelésé 1,84 t/ha volt, azaz a természetes vízellátottság mellett az ilyen adagú mútrágyázás nem csak rosszul hasznosul, de közvetlenül is csökkenti a várható termés nagyságát. A tenyészidei vízpótlás mellett a két kezelés többlettermése közel azonos, 3,56, ill. 3,53 t/ha, vagyis a nagy adagú tápanyag- 
1. ábra. Eltérô hosszúságú referencia-idôszakok csapadékösszegeinek összefüggése a mütrágyakezelések terméshozamával öntözött és öntözetlen állományokban

$$
\text { (1990-2007) }
$$

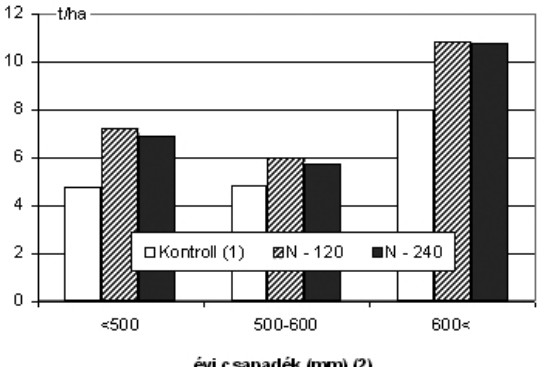

évi c sapadék (mm) (2)
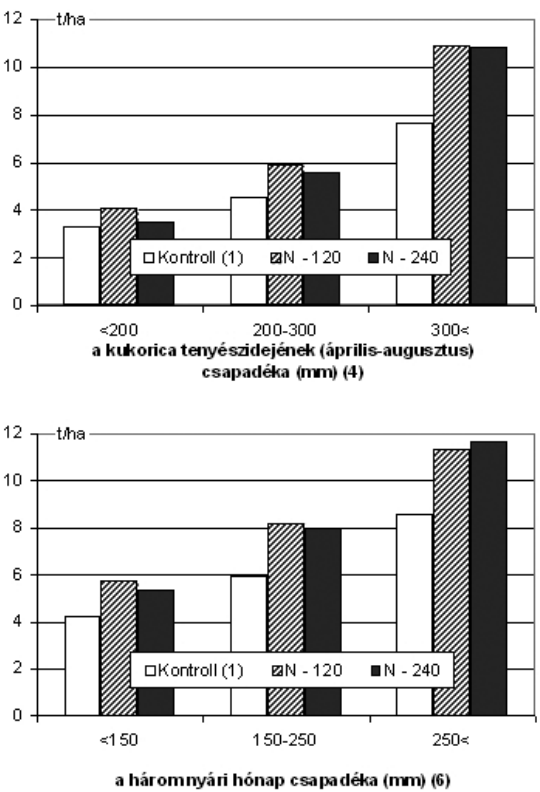

Öntözetlen állomány (8)
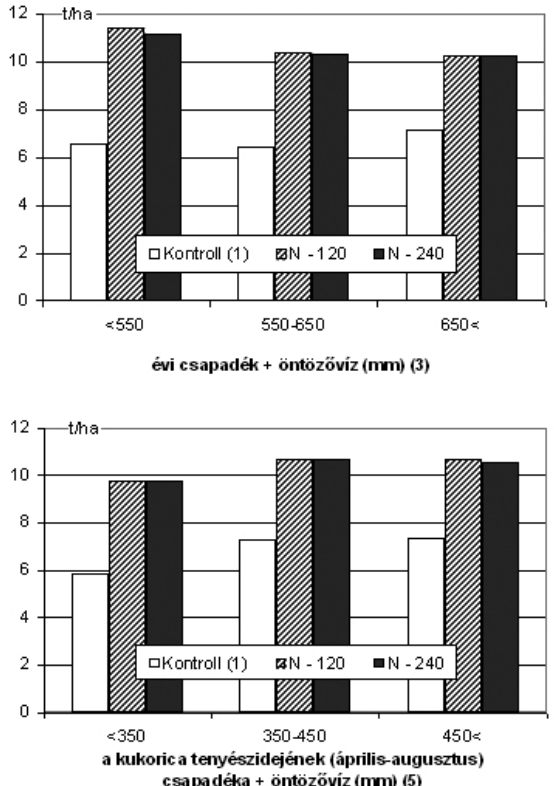

csapa déka + öntözövíz $(\mathrm{mm})(5)$

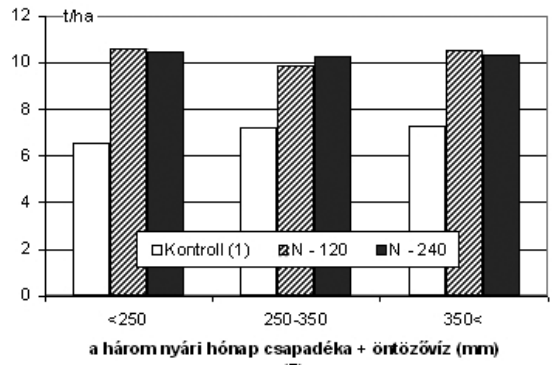

\section{Öntözött állomány (9)}

Figure 1. The correlation of different length reference periods' precipitation sums with the yield obtained as a result of fertiliser treatments in irrigated or non-irrigated populations (1990-2007). (1) Control, (2) Yearly precipitation $(\mathrm{mm})$, (3) Yearly precipitation + irrigation water $(\mathrm{mm})$, (4) Precipitation during the growing season of maize (April-August) $(\mathrm{mm})$, (5) Precipitation during the growing season of maize (April-August) + irrigation water $(\mathrm{mm}),(6)$ Precipitation during the three summer months $(\mathrm{mm})$, (7) Precipitation during the three summer months + irrigation water (mm), (8) Non-irrigated population, (9) Irrigated population. 
kezelés marginálisnál itt is egyértelmúen rosszabb hatásfokúnak bizonyult. Az öntözés által eredményezett termésnövekményt vizsgálva megállapítható, hogy a mútrágyázás nélküli állomány esetében átlagosan 1,3, N-120-as kezelésnél 2,89, míg N-240-es kezelési szintnél 3,09 tonnával emelkedett a várható hozam hektáronként. A vizsgálatok gerincét azonban nem ezen tények megállapítása, hanem a különbözô vízellátási mérôszámokkal történô összevetésük adta. A 2 . ábra mutatja be az öntözött és öntözetlen állományok tulajdonképpeni „vízreakcióját" a háromféle mútrágyakezelés mellett, természetes vízellátottságra vonatkoztatva.

2. ábra. A javuló természetes vizellátottság termésmennyiségre gyakorolt hatásának összevetése öntözött és öntözetlen állomány esetében

(1990-2007)
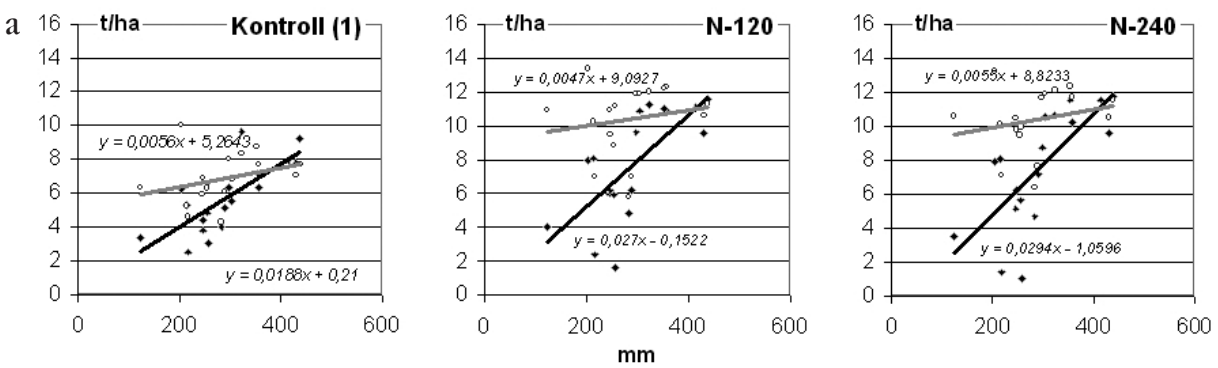

+ Öntözetlen (3) • Öntözött (4) -Lineáris trend (öntözetlen) (5) - Lineáris trend (öntözött) (6)
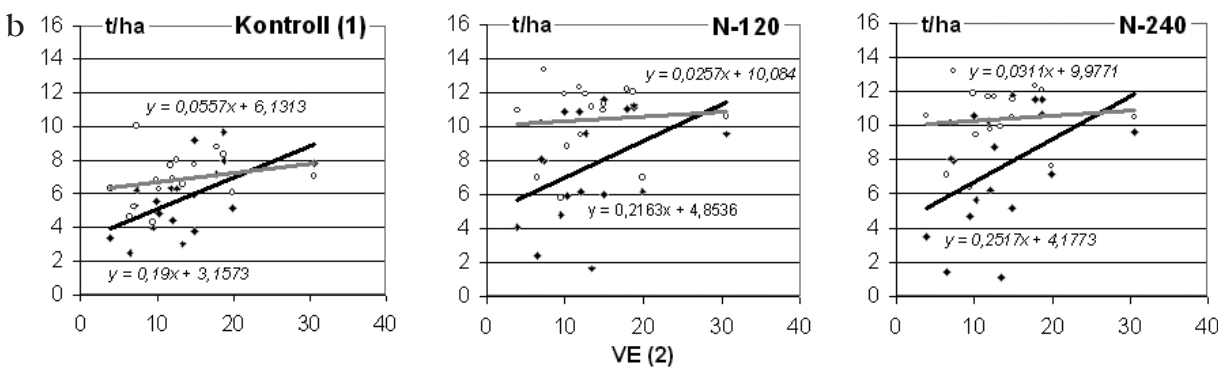

• Öntözetlen (3) • Öntözött (4) —Lineáris trend (öntözetlen) (5) - Lineáris trend (öntözött) (6)

Figure 2. The comparison of the effect of the improving natural water supply on yield in the case of irrigated and non-irrigated populations (1990-2007). (1) Control, (2) Water supply, (3) Non-irrigated, (4) Irrigated, (5) Linear trend (non-irrigated), (6) Linear trend (irrigated). 
A kis esetszámból következően többnyire viszonylag nagy illesztési hiba mellett (r értéke tág határok, általában 0,01 és 0,76 között változik), azonban egyértelmúen látható módon mind az öntözött, mind pedig az öntözetlen állományok termése nô a csapadékmennyiségekkel (2a. ábra) és a vízellátottsági indexszel (2b. ábra) egyaránt. Öntözött körülmények között továbbá a trágyadózisok növekedtével a trendfüggvény meredeksége (m) is konzekvensen nô, ami szoros tápanyag-vízreakció kölcsönhatásra utal a vizsgált kukoricaállományoknál. A nem öntözött parcellákhoz tartozó egyenesek meredeksége ugyancsak pozitív szám, de ezek képe megtévesztô lehet. Eleve kisebb (m) értékeiket az indokolja, hogy a viszonyítási alap az egységesség kedvéért mindkét kezelésnél a természetes csapadékmennyiség volt, ám indirekt módon így is következtethetünk a vízellátottság termésnövelő hatásának mértékére. A teljes rendelkezésre álló vízmennyiségre vonatkoztatva két kezelés egyeneseinek meredeksége megegyezne, lefutásuk párhuzamos lenne. Minél nagyobb az öntözéses kezelés (m) értékének csökkenése - ehhez viszonyítva -, annál nagyobb a pótlólagos vízmennyiség hatása a többlettermés kialakulásában. A kétféle kezelés ily módon történő összehasonlítása azonban módot ad arra, hogy az egyenesek metszéspontjainak x-tengelyre vetítésével meghatározhassunk egy elméleti vízellátottsági értéket, ahol a két kezelés terméshozama azonos. Az ábra tanúsága szerint tehát a tápanyagszinttől függóen hozzávetôleg 380-420 mm április-augusztusi idôszakra vonatkoztatott csapadékösszegnél, illetve VE=22-28 körüli értékénél helyezkedik el az a hangsúlyozottan elméleti határ, mely fölött az öntözés már biztosan nem járhat szignifikáns termésnövelố hatással. Utalva az 1. pontban már meghatározásra került 350-400 mm-es tenyészidei csapadékösszegre - mint a tápanyag-hasznosulás növekedésének marginális csapadék-ellátottsági szintjére - a két kapott eredmény egymást erôsíteni látszik. Mivel az április-augusztusi időszak havi normálösszegei (1881-2009.) rendre 45-60-73-65-58, teljes összege pedig cca. 300 mm, az öntözés szükségessége még átlagos évjáratokban is egyértelmúen igazoltnak mondható. Egyúttal kalkulálható egy, az esztendők legtöbbjében a mútrágyázott kukoricaállományok számára kielégítő öntözővíz mennyiség is, melynek nagysága a fentiek alapján 80-120 mm lehet, amennyiben tenyészidôszaki öntözésrôl beszélünk.

Az öntözéses kezelések szemtermés idősorát használtuk fel annak szemléltetésére, hogy a VE-index végeredményben mennyivel fejezi ki jobban a tényleges vízellátottságot, mint a csapadékösszegen alapuló számítások. A 3. ábra oszlopai a kukorica termését ábrázolják trágyakezelésenként, míg a vonaldiag- 
ramok a két alapul vett vízellátottsági mérôszám április-augusztus bázisú számértékeit mutatják.

3. ábra. Az április-augusztusi időszakra vonatkozó vizellátottsági mérőszámok és a mütrágyakezelések eredményének összefüggése öntözött termés idösoron (1990-2007)

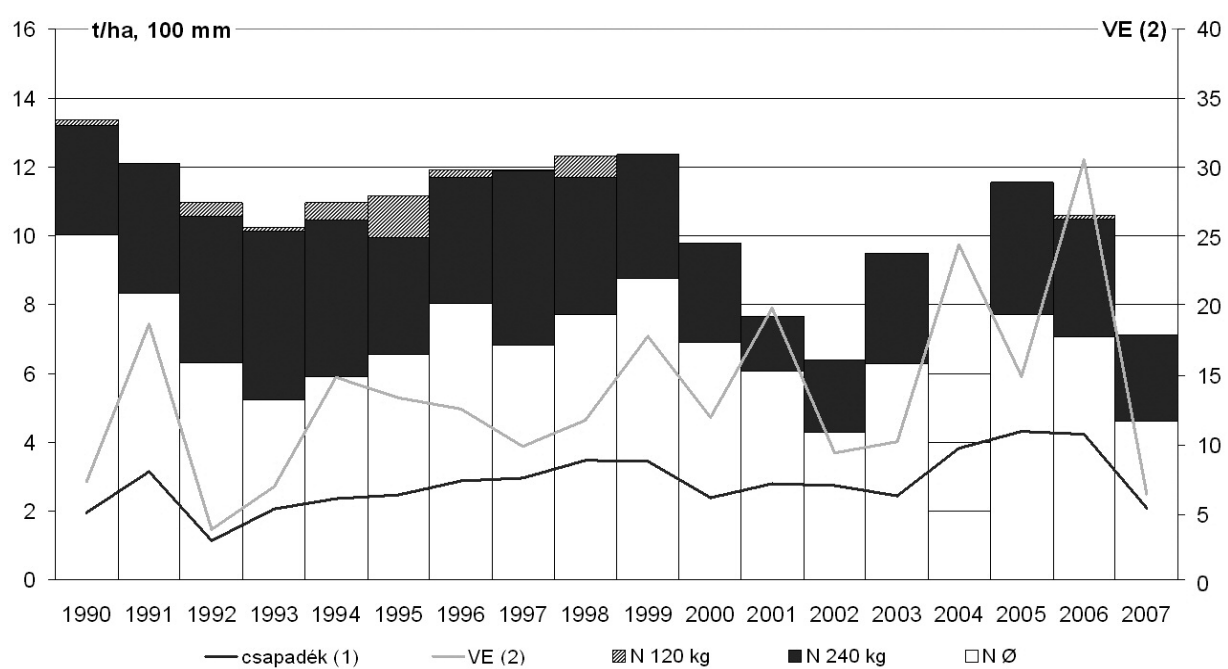

Figure 3. The correlation between the water supply index numbers of the April-August period and the result of the fertiliser treatments in an irrigated yield time series (1990-2007). (1) Precipitation, (2) Water supply.

Az adatsoroknál szembetúnő, hogy egyik mérôszám sincs kimondottan szoros korrelációban a termésadatokkal, de a kettố közül mindenképpen a VEértékek az informatívabbak. Leolvasható, hogy hozzávetôleg 15-ös érték felett csökken minimálisra a N-120 mútrágyakezelés hozamtöbblete a N-240-hez képest, illetve ekkor fordul eló gyakrabban, hogy a nagy dózisú kezelés okozza a legnagyobb termést. A vizsgált éveken megközelítőleg fele-fele arányban osztozott a N-120 illetve a N-240 kezelés, mint legnagyobb termést adó mútrágyadózis. Általánosságban elmondható, hogy a bôségesebb vízellátású évjáratokban szerepelt jobban a nagyobb mútrágyaadagú kezelés, míg a szárazabbakban a kisebb adagok hozama lett nagyobb. Több ízben akad ugyanakkor eltérés az említett szabályszerúségtôl, ezt azonban csak esetenként magyarázza a kijuttatott öntözóvíz változó mennyisége. 
Az öntözéses kezelések termésnövelő hatásának vizsgálata kapcsán részletesebben ki kell még térni az öntözés természetes csapadékhasznosulásra gyakorolt hatására. A megnövelt rendelkezésre álló vízmennyiség, azaz a vízellátottság javulásának hatása elsődlegesen a növekvố termésnagyságon keresztül érvényesül. Másfelől természetes, hogy a nagyobb vízadagok a vízhasznosulási együttható értékét csökkentik, azonban különösen a mútrágyával is kezelt állományok esetében elvárható, hogy a kielégítően nagy vízadagú öntözés a WUE értékét az öntözés nélküli állományok vízhasznosulási szintje fölé növelje. Ezen túlmenően a termésbiztonság javítása is fontos cél az öntözés tervezésekor, így a termés mennyisége és a WUE értéke tekintetében egyaránt a szóródás csökkenését várhatjuk.

A tartamkísérlet terméseredményeinek az április-augusztusi csapadékösszegekkel történő összevetésekor az alábbi WUE értékek adódtak. Az öntözés nélkül beállított parcellák közül a nem mútrágyázott kontroll kezelés 17 év átlagában 19,72 kg, a N-120-as kezelés 26,58, a N-240-es pedig 25,59 kg szemtermést produkált a csapadék minden mm-ére. A három kezelés közül legjobban tehát a $120 \mathrm{~kg}$ nitrogén hatóanyagot tartalmazó mútrágyaadaggal ellátott állomány hasznosította a csapadékvizet. Meg kell azonban említeni, hogy főként a legmagasabb tápanyag-ellátottsági szinten igen tág határok között (4,1-39,0 kg/mm) ingadozik a WUE, szórása pedig a három kezelésnél rendre $5,3-8,7-9,1 \mathrm{~kg} / \mathrm{mm}$ volt. Ez önmagában is utal a mútrágyázás termésbiztonság csökkentô hatására, amennyiben a megemelkedett vízigény kielégítésérôl nem gondoskodunk. Az öntözött állományok vízhasznosulási együtthatói a három trágyázási szinten a következőképpen alakultak: $\varnothing$ - 17,39, N-120 26,67, N-240 - 26,59 kg/mm. Szembetûnő, hogy a mútrágyázás nélküli kontroll állományok közül az öntözetlen vízhasznosítása a jobb, ami pontosan meg is felel elôzetes várakozásainknak. A megnövelt vízmennyiség arányaiban nagyobb volt a rendelkezésre álló tápanyagkészlethez viszonyítva, a termésnövelés szempontjából így feleslegesnek bizonyult. Mútrágyázás mellett azonban mindkét kezelés esetében meghaladja az öntözött állományok vízhasznosulási együtthatója az öntözetlenekét, legjobb hatásfokkal az öntözött $120 \mathrm{~kg} \mathrm{~N}$ hatóanyagú kezelés használta fel a rendelkezésre álló nedvességet. Jóllehet a három kezelés közül ennél a legnagyobb a WUE szórása is (rendre 3,7-6,6-6,3 $\mathrm{kg} / \mathrm{mm}$ ), azonban az öntözetlen állományhoz képest így is jelentôs a termésbiztonság növekedése. 


\section{Következtetések, megállapítások}

A vízellátottság tényleges mértékének pontos megítélése gyakran problematikus, s abban az esetben is, ha csak időszaki csapadékösszegek állnak rendelkezésre, alapvetô fontosságú a referencia-idôszak helyes megválasztása. Kukorica esetében a vizsgálatok szerint az április-augusztusi időszak csapadékösszege korrelál legjobban a különbözó tápanyagszinteken elért termésmennyiségekkel, ennek hibája az egyszerúbb vízellátottsági indexekével (pl. Szász-féle VE-index) hasonló nagyságrendú.

A fenti elvek mentén vizsgálva a Debrecen-Látóképen beállított többtényezôs kukorica tartamkísérlet mútrágya és öntözéses kezeléseinek terméseredményeit, igazolható volt az ismert törvényszerúség, mely szerint hasonló adottságú termőhelyeken (közepes-jó NPK-ellátottságú csernozjomok) a 120 kg/ha N hatóanyagú mútrágyaadagokat meghaladó dózisok már nem növelik gazdaságos mértékben a termés mennyiségét, sôt, vízpótlás nélkül közvetlen módon csökkentik is azt. Ugyanakkor az öntözés nélküli trágyázás növeli ugyan a vízhasznosulást a nem trágyázott állományokhoz képest, de a termésbiztonság csak a megnövekedett vízigény öntözéssel történô kielégítése mellett nô elfogadható szintre. Újfent megállapítást nyert, hogy a trágyázás és a vízellátottság között pozitív kölcsönhatás van, ezért a gazdaságos termesztéshez e két agrotechnikai tényezô szintjének egymással arányos beállítása mindenkor szükséges. Az említett $120 \mathrm{~kg} / \mathrm{ha}$ nitrogén hatóanyagot tartalmazó tápanyag-ellátottsági szinthez tartozó optimális tenyészidei csapadékösszeg 350-400 mm közötti, figyelembe véve a természetes csapadék tájegységre jellemzô mennyiségét és eloszlási sajátosságait, átlagosan legfeljebb 80-120 mm-es öntözéssel történő kiegészítés javasolható.

\section{Köszönetnyilvánítás}

A publikáció elkészítését a Nemzeti Technológiai Program (NKTH 00210/2008) és a TÁMOP 4.2.1./B-09/1/KONV-2010-0007 támogatta. 


\section{IRODALOM}

Antal E.: 2001. A növényi vízellátottság hazai kérdôjelei a jövő évtizedekben a globális éghajlatváltozás tükrében. [In: Szász G. (szerk.) Dr. sen. Berényi Dénes születésének 100 éves jubileumi ünnepsége. Jubileumi Kiadvány.] DE ATC. Debrecen. 119-145.

Berzsenyi Z.: 1993. A mútrágyázás és az évjárat hatása a kukoricahibridek termesztésére és a N-mútrágyareakciójára tartamkísérletben az 1970-1991. években. Növénytermelés. 42. 1: 49-62.

Csathó P.-Kádár I.-Sarkadi J.: 1989. A kukorica mútrágyázása meszes csernozjom talajon. Növénytermelés. 38. 1: 69-76.

Debreczeni B.: 1994. Ökológiai hatások és a mútrágyázás kapcsolata. [In: Debreczeni B.-Debreczeni B.-né (szerk.) Trágyázási kutatások (1960-1990).] Akadémiai Kiadó. Budapest. 366-398.

Debreczeni B.-né: 1964. A mútrágyák gazdaságos adagjának és arányának vizsgálata öntözött talajokon. Időszerú öntözési kutatások. Vituki. 99-100.

Debreczeni B.-né: 1969. Adatok a kukorica vízháztartásának kérdéseihez. [In: I'só I. (szerk.) Kukoricatermesztési kísérletek 1955-1968.] Akadémiai Kiadó. Budapest. 433-439.

Debreczeni B.-né: 2009. Évjárathatások vizsgálata az OMTK-kísérletek növényeinek termésére. [In: Debreczeni B.-né-Németh T. (szerk.) Az Országos Mútrágyázási Tartamkísérletek (OMTK) kutatási eredményei (1967-2001).] Akadémiai Kiadó. Budapest. 353-389.

Dorogi I.: 1987. A szántóföldi növénytermesztés kemizálása. [In: Hajdú M. (szerk.) A szántóföldi növénytermesztés átalakulása Magyarországon (1950-1980).] Akadémiai Kiadó. Budapest. 110-138.

Hank O.-Frank M.: 1951. Összefüggés a talaj tápanyagellátás és a vízfogyasztás között egyes gazdasági növényeknél. ÖKI Évkönyv 2. Szarvas. 219-230.

Nagy J.-Huzsvai L.: 1995. Az évjárat hatás értékelése a kukorica (Zea mays L.) termésére. Növénytermelés. 44. 4: 385-393.

Nagy J.: 1995. A mútrágyázás hatásának értékelése a kukorica (Zea mays L.) termésére eltérô évjáratokban. Növénytermelés. 44. 5-6: 493-506.

Nagy J.: 2007. Kukoricatermesztés. Akadémiai Kiadó. Budapest. 322-348.

Pummer L.-Krisztián J.-Holló S.-Perényi M.: 1995. A mútrágya - csapadék - termés kapcsolata kukorica tartamkísérlet mérési eredményei alapján. Növénytermelés. 44. 5-6: 535-545.

Ruzsányi L.: 1973. A mútrágyázás hatása egyes szántóföldi növények vízfogyasztására és vízhasznosítására. Növénytermelés. 23. 3: 249-258.

Ruzsányi L.: 1989. Az aszály enyhítésének agrotechnikai lehetôségei. [In: Hanyecz V. (szerk.) Aszály.] ÖKI. Szarvas. 49-54. 
Ruzsányi L.: 1997. A szárazság, az aszály mérséklésének növénytermesztési lehetőségei a Hajdúság és a Közép-Tisza-vidék szántóin. [In: Nyíri L. (szerk.) Az aszálykárok mérséklése.] Mezőgazda Kiadó. Budapest. 42-108.

Shaw, $R$. H.-Dale, R. F.: 1959. Climate and corn yields in Iowa. Weekly Weather and Crop Bulletin. 46. 19: 7-8.

Szalóki S.: 1988. Az öntözéses gazdálkodás újabb kutatási eredményei. Tanulmányok. ÖKI. Szarvas.

Szász G.: 1988. Agrometeorológia. Mezőgazdasági Kiadó. Budapest. 462.

Szász G.: 1991. A nyári aszályhajlam területi eloszlása Magyarországon. Acta Geographica Debrecina. Debrecen. 28-29: 299-308.

Szász G.: 1997. A víz a légkörben, a talajban és a növényben. [In: Szász G.-Tôkei L (szerk.) Meteorológia mezógazdáknak, kertészeknek, erdészeknek.] Mezógazda Kiadó. Budapest. 111-148.

Szász G.: 1998. A természetes vízhasznosulás agrometeorológiai vizsgálatának eredményei. Növénytermelés. 47. 3: 289-300.

Varga-Haszonits Z.-Varga Z.: 1999. Agroklimatológia I. (Éghajlat és növénytermesztés). PATE. Mosonmagyaróvár. 284-325.

A szerzốk levelezési címe - Address of the authors:

Dr. Nagy János

DE AGTC Földhasznosítási, Múszaki és Területfejlesztési Intézet

Debrecen

Böszörményi út 138.

H-4032

Rácz Csaba

DE AGTC Agrometeorológiai Obszervatórium

Debrecen

Böszörményi út 138.

H-4032 